\title{
Effects of Countersink Hole on Driving Torques of Screw in Joints Constructed of Medium Density Fiberboard
}

\author{
Önder TOR \\ Kastamonu University, Forest Industry Engineering, Kastamonu, TURKEY \\ ondertor@kastamonu.edu.tr
}

Received Date: 01.08.2019

Accepted Date: 20.09.2019

\section{Abstract}

Aim of study: The aim of this study was to investigate the effect of countersink along with some other factors affecting screw driving torques in joints made of medium density fiberboard (MDF). There is limited research has been done in the field of screw driving torques in wood based composites. In all of these studies, the specimen consisted of a single wood-based composite material and metal plate which was used for the consistency of the screw driving data. However, in this study, the screw driving torques were obtained by the specimens consisted of two MDF testing blocks jointed by a screw.

Material and Method: In general, there were two main screw driving torques; seating torque (SET) and stripping torque (STT). The MDF testing blocks had dimension of $150 \mathrm{~mm}$ long $\times 75 \mathrm{~mm}$ wide and two different thicknesses were used. For upper testing block, 8-mm-thick MDF and for lower testing block, 18mm-thick MDF were used. Torques measurements were obtained by an adjustable torque screwdriver. Factors were embedded screw orientation (face-to-face and face-to-side), pilot-hole diameter (2.5 and 3.0 $\mathrm{mm}$ ), pilot-hole depth (12 and $16 \mathrm{~mm}$ ) and countersink type (with and without countersink).

Main results: The results of statistical analysis indicated that the four-way interaction among the embedded screw orientation, screw length, countersink type and pilot-hole diameter was significant on the mean SET and STT in the MDF joints.

Highlights: This study will help MDF manufacturers to understand the screw performance of their products in terms of screw driving torques.

Keywords: Pilot-hole Diameter and Depth, Embedded Screw Orientation, Torque Wrench, Countersink Hole

\section{Orta Yoğunluklu Lif Levhalarda Havşa Deliğinin Vidalama Torkları Üzerine Etkisi}

$\ddot{O} \mathbf{z}$

Çalışmanin amacı: Bu çalışmada, orta yoğunluklu lif levhalarda (MDF) havşa deliği ve bazı faktörlerin vidalama tork değerleri üzerine etkileri araştırılmıştır. Bu konu ile ilgili yapılan önceki çalışmalarda, ahşap esaslı malzemelerde vidalama torklarının ölçülebilmesi için metal bir plaka ile kullanılmıştır. Ancak, bu çalışmada vidalama tork değerleri direk olarak iki MDF numunesi alından ve yüzeyden olmak üzere birleştirilerek elde edilmiştir.

Materyal ve Yöntem: Vidalama torkları incelendiğinde iki vidalama torku ön plana çıkmaktadır. Birisi vidanın malzemeye tam olarak oturduğu anda ki vidalama torku (SET) diğeri ise vidanın malzeme içerisinde boşta dönmesinden hemen önce ki maksimum tork (STT) olarak adlandırılır. MDF deney örnekleri $150 \mathrm{~mm}$ uzunluğunda ve $75 \mathrm{~mm}$ eninde kesilmiştir. 8 ve $18 \mathrm{~mm}$ olarak iki farklı kalınlık kullanılmıştır. Vidalama torkları ayarlanabilir tork anahtarı ile ölçülmüştür. Bu araştırmada ki faktörler şu şekildedir; vidalama yönü (malzemenin yüz ve alın kısmı), kılavuz deliği çapı (2.5 ve $3.0 \mathrm{~mm}$ ), kılavuz deliği derinliği (12 ve $16 \mathrm{~mm}$ ) ve havşa deliğinin durumu (havşalı ve havşasız).

Sonuçlar: İstatistiksel analiz sonuçlar, vidalama yönü, kılavuz deliği çapı ve derinliği ve havşa deliğinin durumu arasında ki dörtlü etkileşimin anlamlı olduğunu göstermiştir.

Önemli Vurgular: Bu çalışma, MDF panel üreticilerinin malzemelerinde ki vidalama performansları hakkında önemli bilgiler vermektedir.

Anahtar Kelimeler: Kılavuz Deliği ve Derinliği, Vidalama Yönü, Tork Anahtarı, Havşa Deliği 


\section{Introduction}

Connecting wooden pieces together has been an issue for decades in the terms of stiffness, strength, safety and integrity of the wooden components in construction. The driving screws into any type of a material without a countersink which is defined as a conical hole cut into a manufactured object such as plastic, metal or wood. The countersink allows the head of a countersunk screw placed in the hole to sit flush with or below the surface of the surrounding material. In addition, the countersink removes the burr left from a drilling or tapping operation thereby improving the finish of the product and removing any hazardous sharp edges.

Previous studies related to screw driving torques in oriented strandboard (OSB) (Tor et al., 2015) and PB (Tor et al. 2015; Yu et al., 2015), medium density fiberboard (MDF) (Tor, 2019) and wood plastic composite (Kuang et al., 2017). In these studies, the flush condition termed as SET and defined as that in which screw head was fully seated the surface of material whereas STT defined as the maximum torque after passing the SET and increasing the torque sharply. This is because the formed threads being stripped by the screws. Controlling the torque of screw driven into any type of materials is a crucial issue. If the applied torque is too little, the screw possibly will move and slip in the material. Diversely, applying too much torque on turning screws will cause shearing off or fracturing the formed threads by screw in the material and stripping problems. Driving torque requirements of screw are related to screw length and diameter, panel density, screw penetration depth (Carroll, 1972). Didriksson et al. (1974) evaluated edge splitting tendency of fiberboards by using internal bond (IB) test. The results of the study indicated that the edge splitting tendency of fiberboards was decreased when the pilot-hole diameter was increased from 60 to $85 \%$ of the major diameter of screw which cause low screw holding capacity in the joints.

The objectives of this study were to 1 ) obtain SET and STT values, 2) to investigate the effects of countersink hole along with pilot-hole diameter and depth, embedded screw orientation in joints made of MDF, 3) quantify the significant factors on the SET and
STT. The results from this study will help MDF manufacturers to improve the strength and stability of any structure made of their MDF products in terms of fastening by screws. Therefore, the boundary of torque measurements between SET and STT should carefully set to prevent issues with non-seated and stripped screws. For this reason, the STTto-SET ratio can help to have a good margin between the SET and STT. High STT-to-SET ratio minimizes the potential for damage caused by stripping whereas low ratio can be acceptable only for skilled assembly operations.

\section{Materials and Methods \\ Materials and Specimen Preparation}

A full-sized MDF panels received from a factory in Kastamonu, Turkey, measured 2.44 $\mathrm{m}$ long $\times 1.22 \mathrm{~m}$ wide was used. All testing blocks were kept in equilibrium moisture content chamber at $20 \pm 3^{\circ} \mathrm{C}$ and $65 \pm 5$ relative humidity for two weeks (ASTM D 4442-92, 2010). The experiments were divided into two groups based on having a countersink or not. In group \#1, a shallow hole drilled by a countersink drill bit into the face of the upper MDF testing block at almost half thickness to make the screw head flush whereas there was no shallow hole drilled in the testing blocks in group \#2. In addition, the pilot-hole diameters were drilled at the rest of the thickness in the upper testing block. In the case of lower MDF testing blocks, the pilot hole-depths were $65 \%$ and $80 \%$ of the screw length which made the pilot-hole depth 16 and $20 \mathrm{~mm}$ in the MDF joints. Both testing blocks were drilled by 2.5 and $3.0 \mathrm{~mm}$ drill bits which were 70 and $83 \%$ of the screw major diameter (ASTM D1761-06 and D1037-06, 2010).

\section{Experimental Design}

In order to evaluate factors on SET and STT in the MDF joints, a four-factor factorial experiment with 15 replicates per combination was conducted. These four factors were embedded screw orientation (face-to-face and face-to-side), pilot-hole diameter $(2.5$ and $3.0 \mathrm{~mm})$, pilot-hole depth (16 and $20 \mathrm{~mm}$ ) and countersink type (with and without countersink). The face of a specimen was the panel surface and named as face-to-face oriented MDF joint. The side of 
the specimen was either edge parallel or end parallel to panel machine direction since there was no significant difference between edgeand end-embedded screw orientations in terms of screw driving torques (Tor et al. 2015) and named as face-to-side oriented MDF joints (Figure 1c and 1d). Therefore, a total of 480 tests on SET and STT was performed on 240 MDF testing blocks. The testing blocks had dimension of $150 \mathrm{~mm}$ long $\times 75 \mathrm{~mm}$ wide and two different thicknesses were used as $8 \mathrm{~mm}$ thick MDF for upper MDF testing block and $18 \mathrm{~mm}$ thick lower MDF testing block.

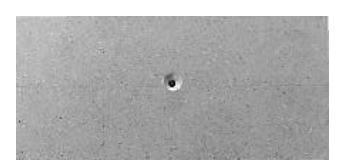

a)

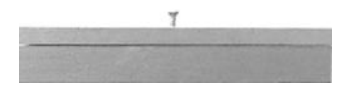

c)

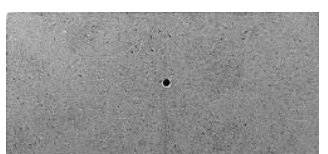

b)

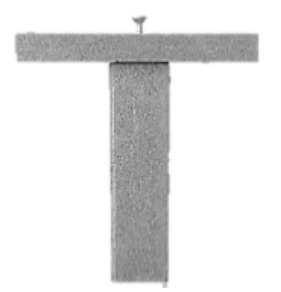

d)
Figure 1. The upper MDF testing blocks with a countersink (a) and without a countersink (b); face-to-face (c) and face-to-side (d) oriented MDF joints

\section{Torque Measurements}

The torque measurement apparatus consisted of two different Kraftform adjustable torque screwdrivers varied based on the torque ranges (Wuppertal, Germany) (Figure 2). The torque of controlled screwdrivers ranged from 0.3 to $1.2 \mathrm{~N} . \mathrm{m}$ and 1.2 to 3.0 N.m, respectively. They had distinctly audible and noticeable excess-load signal when the required torque was reached. The measurement accuracy was $\pm 6 \%$ accordance with the standard of ISO 6789-2.

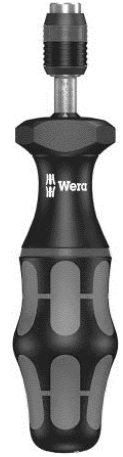

a)

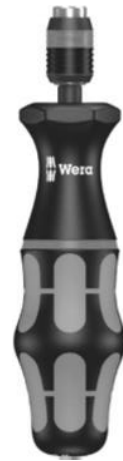

b)
Figure 2. Kraftform adjustable torque screwdrivers. The torque ranged from 0.3 to 1.2 N.m (a) and 1.2 to 3.0 N.m (b).

\section{Results and Discussion}

Mean SET and STT values and their coefficient of variance values are given in Table 1 which also shows the ratios of STTto-SET for each treatment combination. In general, the ratio of STT-to-SET ranged from 2.0 to 2.6 for face-to-face oriented MDF joints within both countersink types whereas the ratio ranged from 1.7 to 2.2 for the face-toside oriented MDF joints. Overall, the ratios less than 3, the operator needs to be careful when driving screws in this type of joints (Robert, 2012).

\section{Mean SET and STT Comparisons}

The STT had significantly higher values than SET (Table 1). Thus, a general linear model procedure for a four-factor balanced analysis of variance (ANOVA) was performed in order to analyze four main effects and their interactions on means of SET and STT of screws driven in MDF joints separately. The ANOVA results indicated that the four-factor interaction was statistically significant on SET and STT at the 5\% significance level (Table 2). Thus, the protected least significant difference (LSD) multiple comparisons procedure was needed to be performed to compare the mean difference. A one-way classification of 16 combinations was created for both SET and STT data sets to evaluate the mean differences among the combinations using LSD values of 0.0362 N.m and 0.0601 N.m for data sets with respect to the four interaction, respectively. All outputs were provided by SAS software 2014 (SAS Institute Inc. Cary, NC, USA). 
Table 1. Mean values of SET and STT of driving screws into MDF joints.

\begin{tabular}{|c|c|c|c|c|c|c|}
\hline \multirow{2}{*}{$\begin{array}{l}\text { Countersink } \\
\text { hole type }\end{array}$} & \multirow{2}{*}{$\begin{array}{c}\text { Screw } \\
\text { embedded } \\
\text { orientation }\end{array}$} & \multirow{2}{*}{$\begin{array}{l}\text { Pilot-hole } \\
\text { depth } \\
(\mathrm{mm})\end{array}$} & \multirow{2}{*}{$\begin{array}{l}\text { Pilot-hole } \\
\text { diameter } \\
(\mathrm{mm})\end{array}$} & \multicolumn{2}{|c|}{$\begin{array}{l}\text { Screw driving torques } \\
\text { (N.m) }\end{array}$} & \multirow[t]{2}{*}{$\begin{array}{c}\text { Ratio } \\
\text { STT/SET }\end{array}$} \\
\hline & & & & SET & STT & \\
\hline \multirow{8}{*}{$\mathrm{C}$} & \multirow{4}{*}{ Face-to-face } & \multirow{2}{*}{16} & 2.5 & $0.97(8)^{*}$ & $2.07(3)$ & 2.1 \\
\hline & & & 3 & $0.83(11)$ & $1.71(5)$ & 2.3 \\
\hline & & \multirow{2}{*}{20} & 2.5 & $0.85(4)$ & $1.85(4)$ & 2.2 \\
\hline & & & 3 & $0.63(9)$ & $1.68(5)$ & 2.6 \\
\hline & \multirow{4}{*}{ Face-to-side } & \multirow{2}{*}{16} & 2.5 & $0.40(10)$ & $0.82(11)$ & 2.0 \\
\hline & & & 3 & $0.30(4)$ & $0.56(13)$ & 1.8 \\
\hline & & \multirow{2}{*}{20} & 2.5 & $0.33(10)$ & $0.71(13)$ & 2.2 \\
\hline & & & 3 & $0.31(7)$ & $0.53(13)$ & 1.7 \\
\hline \multirow{8}{*}{$\mathrm{NC}$} & \multirow{4}{*}{ Face-to-face } & \multirow{2}{*}{16} & 2.5 & $0.82(4)$ & $1.81(5)$ & 2.2 \\
\hline & & & 3 & $0.74(10)$ & $1.51(13)$ & 2.1 \\
\hline & & \multirow{2}{*}{20} & 2.5 & $0.78(12)$ & $1.76(2)$ & 2.3 \\
\hline & & & 3 & $0.67(7)$ & $1.34(5)$ & 2.0 \\
\hline & \multirow{4}{*}{ Face-to-side } & \multirow{2}{*}{16} & 2.5 & $0.42(6)$ & $0.86(9)$ & 2.0 \\
\hline & & & 3 & $0.35(6)$ & $0.61(6)$ & 1.7 \\
\hline & & \multirow{2}{*}{20} & 2.5 & $0.31(13)$ & $0.63(5)$ & 2.0 \\
\hline & & & 3 & $0.30(4)$ & $0.49(9)$ & 1.8 \\
\hline
\end{tabular}

${ }^{*}$ Values in parantheses are coefficient of variation $(\%)$.

Table 2. Summary of ANOVA results

\begin{tabular}{lcccc}
\hline \multirow{2}{*}{ Source } & \multicolumn{2}{c}{ SET } & \multicolumn{2}{c}{ STT } \\
\cline { 2 - 5 } & F-value & p-value & F-value & p-value \\
\hline Countersink hole type & 6.9 & $<.0001$ & 109.8 & $<.0001$ \\
\hline Screw embedded orientation & 4381 & $<.0001$ & 9775.3 & $<.0001$ \\
\hline Pilot-hole depth & 262.79 & $<.0001$ & 580.29 & $<.0001$ \\
\hline Pilot-hole diameter & 114.5 & $<.0001$ & 126.61 & $<.0001$ \\
\hline 2-way interactions & $0.1-47.82$ & $0.749-<.0001$ & $0.01-95.7$ & $0.9078-<.0001$ \\
\hline 3-way interactions & $2.17-17.35$ & $0.0 .142-<.0001$ & $2.27-10.3$ & $0.133-<.0001$ \\
\hline 4-way interaction & 0.33 & 0.0021 & 15.25 & 0.0001 \\
\hline
\end{tabular}

\section{Pilot-hole Effects}

In general, mean SET and STT values of MDF joints drilled by the pilot-hole diameter of $2.5 \mathrm{~mm}$ was higher than the corresponding ones at $3.0 \mathrm{~mm}$ since less fibers were cut through by a screw at the $3.0 \mathrm{~mm}$-pilot-hole diameter than the ones at the $2.5 \mathrm{~mm}$. This decrease could also be because of less friction force between the surfaces of the screw itself in the material ( $\mathrm{Yu}$ et al. 2015). Even though the pilot-hole diameter of $2.5 \mathrm{~mm}$ had higher SET than the ones at the $3.0 \mathrm{~mm}$, there was no statistically significant difference among the pilot-hole diameters in the case of driving screw with the pilot-hole depth of $12 \mathrm{~mm}$ in the face-to-side oriented MDF joints with and without the countersink on the top. In all other combinations, the pilot-hole diameter of 2.5 had higher mean SET and STT than the ones at the $3.0 \mathrm{~mm}$ (Table 3). In general, the mean SET and STT values when the pilot-hole depth was $8 \mathrm{~mm}$ in the MDF joints was higher than the corresponding ones at $12 \mathrm{~mm}$ (Table 4). Most of the cases, there was statistically significant difference between the pilot-hole depths of 8 and $12 \mathrm{~mm}$ where the 8 - $\mathrm{mm}$ pilothole depth had higher SET and STT than the $12 \mathrm{~mm}$. 
Table 3. Mean comparisons of SET and STT in MDF joints for pilot-hole diameters within each combination of pilot-hole depth, screw embedded orientation and countersink type.

\begin{tabular}{|c|c|c|c|c|c|c|}
\hline \multirow{3}{*}{$\begin{array}{l}\text { Countersink } \\
\text { hole type }\end{array}$} & \multirow{3}{*}{$\begin{array}{c}\text { Screw } \\
\text { embedded } \\
\text { orientation }\end{array}$} & \multirow{3}{*}{$\begin{array}{c}\text { Pilot-hole } \\
\text { depth (mm) }\end{array}$} & \multicolumn{2}{|c|}{ SET } & \multicolumn{2}{|c|}{ STT } \\
\hline & & & \multicolumn{4}{|c|}{ Pilot-hole diameter (mm) } \\
\hline & & & 2.5 & 3 & 2.5 & 3 \\
\hline \multirow{4}{*}{ C } & \multirow{2}{*}{ Face-to-face } & 16 & $0.97 \mathrm{~A}^{*}$ & $0.83 \mathrm{~B}$ & $2.07 \mathrm{~A}$ & $1.71 \mathrm{~B}$ \\
\hline & & 20 & $0.85 \mathrm{~A}$ & $0.63 \mathrm{~B}$ & $1.85 \mathrm{~A}$ & $1.68 \mathrm{~B}$ \\
\hline & \multirow{2}{*}{ Face-to-side } & 16 & $0.40 \mathrm{~A}$ & $0.30 \mathrm{~B}$ & $0.82 \mathrm{~A}$ & $0.56 \mathrm{~B}$ \\
\hline & & 20 & $0.33 \mathrm{~A}$ & $0.31 \mathrm{~A}$ & $0.71 \mathrm{~A}$ & $0.53 \mathrm{~B}$ \\
\hline \multirow{4}{*}{$\mathrm{NC}$} & \multirow{2}{*}{ Face-to-face } & 16 & $0.82 \mathrm{~A}$ & $0.74 \mathrm{~B}$ & $1.81 \mathrm{~A}$ & $1.51 \mathrm{~B}$ \\
\hline & & 20 & $0.78 \mathrm{~A}$ & $0.67 \mathrm{~B}$ & $1.76 \mathrm{~A}$ & $1.34 \mathrm{~B}$ \\
\hline & \multirow{2}{*}{ Face-to-side } & 16 & $0.42 \mathrm{~A}$ & $0.35 \mathrm{~B}$ & $0.86 \mathrm{~A}$ & $0.61 \mathrm{~B}$ \\
\hline & & 20 & $0.31 \mathrm{~A}$ & $0.30 \mathrm{~A}$ & $0.63 \mathrm{~A}$ & $0.49 \mathrm{~B}$ \\
\hline
\end{tabular}

* Means followed by a common letter are not significantly different at the 5\% level.

Table 4. Mean comparisons of SET and STT in MDF joints for pilot-hole depth within each combination of pilot-hole diameter, screw embedded orientation and countersink type. ${ }^{\mathrm{a}}$

\begin{tabular}{|c|c|c|c|c|c|c|}
\hline \multirow{3}{*}{$\begin{array}{l}\text { Countersink } \\
\text { hole type }\end{array}$} & \multirow{3}{*}{$\begin{array}{c}\text { Screw } \\
\text { embedded } \\
\text { orientation }\end{array}$} & \multirow{3}{*}{$\begin{array}{l}\text { Pilot-hole } \\
\text { diameter } \\
(\mathrm{mm})\end{array}$} & \multicolumn{2}{|c|}{ SET } & \multicolumn{2}{|c|}{$\begin{array}{l}\text { STT } \\
\end{array}$} \\
\hline & & & \multicolumn{4}{|c|}{ Pilot-hole depth (mm) } \\
\hline & & & 16 & 20 & 16 & 20 \\
\hline \multirow{4}{*}{$\mathrm{C}$} & \multirow{2}{*}{ Face-to-face } & 2.5 & $0.97 \mathrm{~A}$ & $0.85 \mathrm{~B}$ & $2.07 \mathrm{~A}$ & $1.85 \mathrm{~B}$ \\
\hline & & 3.0 & $0.83 \mathrm{~A}$ & $0.63 \mathrm{~B}$ & $1.71 \mathrm{~A}$ & $1.68 \mathrm{~A}$ \\
\hline & \multirow{2}{*}{ Face-to-side } & 2.5 & $0.40 \mathrm{~A}$ & $0.33 \mathrm{~B}$ & $0.82 \mathrm{~A}$ & $0.71 \mathrm{~B}$ \\
\hline & & 3.0 & $0.30 \mathrm{~A}$ & $0.31 \mathrm{~A}$ & $0.56 \mathrm{~A}$ & $0.53 \mathrm{~A}$ \\
\hline \multirow{4}{*}{$\mathrm{NC}$} & \multirow{2}{*}{ Face-to-face } & 2.5 & $0.82 \mathrm{~A}$ & $0.78 \mathrm{~B}$ & $1.81 \mathrm{~A}$ & $1.76 \mathrm{~A}$ \\
\hline & & 3.0 & $0.74 \mathrm{~A}$ & $0.67 \mathrm{~B}$ & $1.51 \mathrm{~A}$ & $1.34 \mathrm{~B}$ \\
\hline & \multirow{2}{*}{ Face-to-side } & 2.5 & $0.42 \mathrm{~A}$ & $0.31 \mathrm{~B}$ & $0.86 \mathrm{~A}$ & $0.63 \mathrm{~B}$ \\
\hline & & 3.0 & $0.35 \mathrm{~A}$ & $0.30 \mathrm{~B}$ & $0.61 \mathrm{~A}$ & $0.49 \mathrm{~B}$ \\
\hline
\end{tabular}

* Means followed by a common letter are not significantly different at the 5\% level.

\section{Screw Embedded Orientation Effects}

In general, the mean SET values ranged from 0.63 to 0.97 N.m for the face-to-face oriented MDF joint and from 0.30 to 0.42 N.m for the face-to-side oriented MDF joint while the STT mean values ranged from 1.34 to 2.07 N.m for the face-to-face orientation and from 0.49 to 0.82 for the face-to-side orientation (Table 5). In the case of mean comparison of screw embedded screw orientations, the mean SET and STT values for the face-to-face orientation was higher than the corresponding ones for the face-to-side orientation in all combinations of pilot-hole diameter, pilothole depth and countersink type. This could be explained by the density profile of the MDF material. The MDF material used in this study had three layers of different densities as manufactured in the panel company. The upper and lower surface layers had higher densities which were about $0.85 \mathrm{~g} / \mathrm{cm}^{3}$ at the 1 $\mathrm{mm}$ thickness of both layers while the core density was about $0.50 \mathrm{~g} / \mathrm{cm}^{3}$ at the $6 \mathrm{~mm}$ thickness of middle layer. For the face-to-side orientation, when the screw was driven into
MDF joints, the screw penetrated into the middle layer of MDF material after passing through the upper MDF face testing block. This can lead to a decrease of SET and STT in side orientation because of lower core density. This can also lead to cause minor splits and cracks which can lower STT values when the pilot-hole diameter is less than $2.5 \mathrm{~mm}$. Therefore, the pilot-hole diameter needs to be chosen very carefully when driving screw into this kind of materials.

\section{Countersink Hole Type Effects}

In general, the mean SET and STT values were higher when a countersink (C) was drilled in middle of the upper MDF testing block in the joints than the ones without the countersink (NC) in all combinations except one case (Table 6). The mean SET in the face-to-face oriented MDF joint with no countersink on the top with the $3.0 \mathrm{~mm}$-pilothole diameter and depth of $20 \mathrm{~mm}$ was significantly higher than the corresponding ones with the countersink on the top of upper testing block. 
Table 5. Mean comparisons of SET and STT in MDF joints for screw embedded orientation within each combination of pilot-hole diameter, pilot-hole depth, and countersink type.

\begin{tabular}{|c|c|c|c|c|c|c|}
\hline \multirow{3}{*}{$\begin{array}{l}\text { Countersink } \\
\text { hole type }\end{array}$} & \multirow{3}{*}{$\begin{array}{c}\text { Pilot-hole } \\
\text { depth } \\
(\mathrm{mm})\end{array}$} & \multirow{3}{*}{$\begin{array}{l}\text { Pilot-hole } \\
\text { diameter } \\
(\mathrm{mm})\end{array}$} & \multicolumn{2}{|c|}{ SET } & \multicolumn{2}{|c|}{ STT } \\
\hline & & & \multicolumn{4}{|c|}{ Screw embedded orientation } \\
\hline & & & Face-to-face & Face-to-side & Face-to-face & Face-to-side \\
\hline \multirow{4}{*}{$\mathrm{C}$} & \multirow{2}{*}{16} & 2.5 & $0.97 \mathrm{~A}$ & $0.40 \mathrm{~B}$ & $2.07 \mathrm{~A}$ & $0.82 \mathrm{~B}$ \\
\hline & & 3.0 & $0.83 \mathrm{~A}$ & $0.30 \mathrm{~B}$ & $1.71 \mathrm{~A}$ & $0.56 \mathrm{~B}$ \\
\hline & \multirow{2}{*}{20} & 2.5 & $0.85 \mathrm{~A}$ & $0.33 \mathrm{~B}$ & $1.85 \mathrm{~A}$ & $0.71 \mathrm{~B}$ \\
\hline & & 3.0 & $0.63 \mathrm{~A}$ & $0.31 \mathrm{~B}$ & $1.68 \mathrm{~A}$ & $0.53 \mathrm{~B}$ \\
\hline \multirow{4}{*}{$\mathrm{NC}$} & \multirow{2}{*}{16} & 2.5 & $0.82 \mathrm{~A}$ & $0.42 \mathrm{~B}$ & $1.81 \mathrm{~A}$ & $0.86 \mathrm{~B}$ \\
\hline & & 3.0 & $0.74 \mathrm{~A}$ & $0.35 \mathrm{~B}$ & $1.51 \mathrm{~A}$ & $0.61 \mathrm{~B}$ \\
\hline & \multirow{2}{*}{20} & 2.5 & $0.78 \mathrm{~A}$ & $0.31 \mathrm{~B}$ & $1.76 \mathrm{~A}$ & $0.63 \mathrm{~B}$ \\
\hline & & 3.0 & $0.67 \mathrm{~A}$ & $0.30 \mathrm{~B}$ & $1.34 \mathrm{~A}$ & $0.49 \mathrm{~B}$ \\
\hline
\end{tabular}

*Means followed by a common letter are not significantly different at the 5\% level.

Table 6. Mean comparisons of SET and STT in MDF joints for countersink type within each combination of pilot-hole diameter, pilot-hole depth, and screw embedded orientation.

\begin{tabular}{|c|c|c|c|c|c|c|}
\hline \multirow{3}{*}{$\begin{array}{c}\text { Screw } \\
\text { embedded } \\
\text { orientation }\end{array}$} & \multirow{3}{*}{$\begin{array}{c}\text { Pilot-hole } \\
\text { depth (mm) }\end{array}$} & \multirow{3}{*}{$\begin{array}{l}\text { Pilot-hole } \\
\text { diameter } \\
(\mathrm{mm})\end{array}$} & \multicolumn{2}{|c|}{ SET } & \multicolumn{2}{|c|}{ STT } \\
\hline & & & \multicolumn{4}{|c|}{ Countersink hole type } \\
\hline & & & $\mathrm{C}$ & $\mathrm{NC}$ & $\mathrm{C}$ & $\mathrm{NC}$ \\
\hline \multirow{4}{*}{ Face-to-face } & \multirow{2}{*}{16} & 2.5 & $0.97 \mathrm{~A}$ & $0.82 \mathrm{~B}$ & $2.07 \mathrm{~A}$ & $1.81 \mathrm{~A}$ \\
\hline & & 3.0 & $0.83 \mathrm{~A}$ & $0.74 \mathrm{~B}$ & $1.71 \mathrm{~A}$ & $1.51 \mathrm{~B}$ \\
\hline & \multirow{2}{*}{20} & 2.5 & $0.85 \mathrm{~A}$ & $0.78 \mathrm{~B}$ & $1.85 \mathrm{~A}$ & $1.76 \mathrm{~B}$ \\
\hline & & 3.0 & $0.63 \mathrm{~B}$ & $0.67 \mathrm{~A}$ & $1.68 \mathrm{~A}$ & $1.34 \mathrm{~B}$ \\
\hline \multirow{4}{*}{ Face-to-side } & \multirow{2}{*}{16} & 2.5 & $0.40 \mathrm{~A}$ & $0.42 \mathrm{~A}$ & $0.82 \mathrm{~A}$ & $0.86 \mathrm{~A}$ \\
\hline & & 3.0 & $0.30 \mathrm{~A}$ & $0.35 \mathrm{~B}$ & $0.56 \mathrm{~A}$ & $0.61 \mathrm{~A}$ \\
\hline & \multirow{2}{*}{20} & 2.5 & $0.33 \mathrm{~A}$ & $0.31 \mathrm{~A}$ & $0.71 \mathrm{~A}$ & $0.63 \mathrm{~B}$ \\
\hline & & 3.0 & $0.31 \mathrm{~A}$ & $0.30 \mathrm{~A}$ & $0.53 \mathrm{~A}$ & $0.49 \mathrm{~A}$ \\
\hline
\end{tabular}

*Means followed by a common letter are not significantly different at the 5\% level.

\section{Conclusion}

In this study, the experimental results indicated that embedded screw orientation, screw length, countersink type and pilot-hole diameter significantly affected the SET and STT in the MDF joints. The pilot-hole diameter of $2.5 \mathrm{~mm}$ had higher SET and STT values than the one with $3.0 \mathrm{~mm}$ in all combinations of countersink hole type, embedded screw orientation, pilot-hole diameter and depth. The MDF joints with the countersink on the upper testing block had higher SET and STT than the one with no countersink. A possible explanation for this was because of more friction force between contacting surface of head of the screw and the material occurred in the MDF joints and ultimately more screw penetration attained in the joint with the countersink. This study will help MDF manufacturers to understand the screw performance of their products in terms of screw driving torques.

\section{Acknowledgment}

This study was founded by the Kastamonu University, Kastamonu, Turkey (grant number KUBAP01/2017-58).

\section{References}

ASTM D1761-06 (2010). Standard test method for mechanical fasteners in wood. American Society for Testing and Materials, West Conshohocken, PA.

ASTM D 4442-92 (2010). Standard test methods for direct moisture content measurement of wood and wood-base materials. American Society for Testing and materials, West Conshohocken, PA.

ASTM D1037-06 (2010). Standard test methods for evaluating properties of wood-base fiber and particle panel materials. American Society for Testing and materials, West Conshohocken, PA.

Carroll, M. N. (1972). Measuring screw withdrawal with a torque wrench. Forest Products Journal, 22(8), 42-46.

Didriksson, E. I. E., Nyren, J. O. \& Back, E. L. (1974). The splitting of wood-base building 
boards due to edge screwing. Forest Products Journal, 24(7), 35-39.

Kuang, F., Xing, Y., Wu, Z. \& Zhang, J. (2017). Characteristics of screwdriving torques in wood-plastic composites. Wood and Fiber Science, 49(2), 206-218.

Robert, A.M. (2012). Plastic part design for injection molding: An introduction. Hanser Publications, Cincinnati, Ohio. pp. 381-384.

SAS 9.4. (2014). SAS users' guide. SAS Institute, Cary, NC.

Tor, O., Yu, X. \& Zhang, J. (2015). Characteristics of torques for driving screws into wood based composites. Wood and Fiber Science, 47(1), 2 16.

Tor, O. (2019). Effects of pilot hole diameter on screw-driving torques in medium density fiberboard. CERNE, 25(1), 54-59.

Yu, X., Tor, O., Quin, F., Seale, D. \& Zhang, J. (2015). Screw-driving torques in particleboards. Wood and Fiber Science, 47(2), 17-30. 